\title{
Infectious disease among enslaved African Americans at Eaton's Estate, Warren County, North Carolina, ca. 1830-1850
}

\author{
Patricia M Lambert
}

\author{
Anthropology Program, 0730 Old Main Hill, Utah State University, Logan, UT 84322-0730, US
}

\begin{abstract}
The skeletal remains of 17 people buried in the Eaton Ferry Cemetery in northern North Carolina provide a means of examining health and infectious disease experience in the XIX century South. The cemetery appears to contain the remains of African Americans enslaved on the Eaton family estate from approximately 1830-1850, and thus offers a window into the biological impacts of North American slavery in the years preceding the Civil War. The sample includes the remains of six infants, one child, and one young and nine mature adults (five men, four women, and one unknown). Skeletal indices used to characterize health and disease in the Eaton Ferry sample include dental caries, antemortem tooth loss, enamel hypoplasia, porotic hyperostosis, periosteal lesions, lytic lesions, and stature. These indicators reveal a cumulative picture of compromised health, including high rates of dental disease, childhood growth disruption, and infectious disease. Specific diseases identified in the sample include tuberculosis and congenital syphilis. Findings support previous research on the health impacts of slavery, which has shown that infants and children were the most negatively impacted segment of the enslaved African American population.
\end{abstract}

Key words: African American - congenital syphilis - health - slavery - tuberculosis

Human remains from the Eaton Ferry Cemetery on the Roanoke River in northern North Carolina provide a rare opportunity to directly examine the health and disease experience of African Americans in the antebellum South. The life stresses faced by African slaves in the Americas have been much debated by historians and economists, who appeal to a wide range of historic records to reconstruct aspects of the slave existence (e.g. Savitt 1978, 1989, Kelley \& Angel 1987, Steckel 2000). Census, plantation, and probate records, diaries, medical records, and other historic documents offer important insights into the nature of housing, family structure, types and quantities of foods, labor, punishment, disease susceptibility and exposure, and other aspects of life that in combination help to reconstruct the health environment for enslaved African Americans. However, these sources usually derive from slave owners and other members of the dominant society, and therefore tend to reflect the interests and concerns of record keepers rather than those of the enslaved (Savitt 1978, 1989). Birth and death records provide a less biased means of assessing morbidity and mortality, and have contributed substantially to our understanding of the health impacts of slavery in North America (e.g. Steckel 1985, 2000, Hutchinson 1987). The study of human skeletons can complement this historical record by providing a more direct accounting of the biological impacts of slavery on individuals and groups. In this paper, human skeletal remains provide a means to test a hy-

Fiancial support: Research Laboratories of Archaeology at the University of North Carolina at Chapel Hill

E-mail: plambert@hass.usu.edu

Received 20 July 2006

Accepted 16 October 2006 pothesis about health and disease experience generated from historical research.

Background information on the cemetery - When the Eaton Ferry cemetery was discovered in 1961, nothing was apparently known of its provenance; the cemetery was unmarked and none of the graves had stones or other markers. The cemetery was excavated in 1962 by the University of North Carolina at Chapel Hill as part of an archaeological survey for the proposed Gaston Reservoir Project (Phelps 1961, Davis et al. 1996). The primary focus of this extensive archaeological project was Native American sites that would be impacted by flooding associated with the creation of the reservoir. The excavation at $\mathrm{Wr}-4$, the formal designation of the archaeological site containing the historic cemetery (Wr-4B), was initiated to remove cultural deposits from the prehistoric Native American site into which the historic burials intruded. It appears from maps of the excavation that the site was not completely excavated and the true extent of the historic cemetery remains unknown. Apparently, archaeologists considered the cemetery to be an African American burial site, although the reason for this original attribution remains unclear. One of the first tasks in this analysis was to determine the age of the cemetery and the ancestry of the people buried there.

The age of the cemetery was recently determined through the use of time sensitive artifacts. The collections contain associated grave goods from 16 of 17 burials excavated from the cemetery, most commonly simple coffin hardware such as nails and screws, but also upholstery tacks (and some fabric), bits of metal, and in one case simple coffin handles (Table I). The only other grave goods are straight pins (eight individuals), buttons (six individuals), and a single, glass bead. Together, these grave goods led excavators in the 1960s to attribute the cemetery to the mid-late XIX century. Recent analysis of these materials has permitted a more accurate estimation of the use period of the cemetery. In particular, 
several of the personal items have temporal significance associated with their first appearance and common usage: two types of straight pins and a set of Prosser buttons (Table I). Straight pins first came into use in the late XVIII century; these early pins were manufactured from two parts - a wire shaft and a round head. They were replaced in the 1830 s by one-piece, headed pins that became widely available after 1835 (McNulty 2006). Although a few of the burials have the early form of straight pin, most also had the later, single piece version, suggesting that the cemetery largely dates after 1835, a date confirmed by the association of Prosser buttons with one infant burial. Prosser buttons were first manufactured in England by Richard Prosser in 1840 and a year later in America by his brother Thomas (Sprague 2002). However, no safety pins were recovered from any burials; safety pins were patented in 1849 (Kane 1997) and presumably became fairly readily available within the next decade. Together, these artifact dates place the use of the cemetery around $1830-1850 \pm 10$ years, in the years just preceding the Civil War.

Grave goods also convey information about the so- cial standing of the people buried in the cemetery that contributes to their emerging identity. All of the individuals appear to have been buried in wooden coffins, as indicated by coffin hardware (esp. nails and screws) and remnant pieces of wood (Table I). However, handles and other coffin adornments are rare, suggesting that the families of most individuals buried there lacked the means to purchase expensive coffins. In addition, no wedding bands, hair ornaments, or other personal items that might be expected to accompany the dead were recovered with any of the bodies, aside from standard buttons, suggesting that such items were also outside the reach of the people buried there. Indeed, Eaton Ferry Cemetery grave accompaniments place them at the low end of the social spectrum in comparison to many individuals buried in the Cedar Grove African American cemetery of southwestern Arkansas, which appears to date from 1834 to the early part of the XX century (Rose 1985). In sum, the people buried in the Eaton Ferry cemetery do not appear to have had any disposable wealth, suggesting a low economic and social standing.

TABLE I

Description of human remains and associated burial goods from the Eaton Ferry Cemetery (Wr- $4 \mathrm{~b})$

\begin{tabular}{|c|c|c|c|c|c|}
\hline Burial & Age (yrs) & Sex & Ethnicity $a / b$ & Stature $^{c}$ & Associated materials/Artifacts \\
\hline 1 & $39 \pm 9$ & $\mathrm{~F}^{4}$ & Black $^{a 1}$ & - & None, green stains on cranium (disturbed burial) \\
\hline 2 & $45 \pm 13$ & $\mathrm{~F}^{4}$ & Black $^{a l}$ & - & 58 coffin nails, 3 iron screws \\
\hline 3 & $40 \pm 5$ & $\mathrm{M}^{5}$ & White $^{b}$ & $5^{\prime} 4^{\prime \prime} \pm 2.8^{\prime \prime}$ & 48 coffin nails \\
\hline 4 & $>30$ & $?$ & $?$ & - & 12 iron nails \\
\hline 5 & $35 \pm 5$ & $\mathrm{~F}^{5}$ & $(\text { Black? })^{b 1}$ & - & $\begin{array}{l}57 \text { coffin nails, } 1 \text { straight pin, } 9 \text { wooden button } \\
\text { fragments, } 6 \text { metal buttons. Green stain on sternum }\end{array}$ \\
\hline 6 & $1 \pm 0.33$ & $?$ & $?$ & - & 23 coffin nails, 3 straight pins \\
\hline 7 & 0.08 & $?$ & $?$ & - & 25 coffin nails, 5 straight pin fragments \\
\hline 8 & $44 \pm 12$ & $\mathrm{~F}^{d}$ & Black $^{a 4}$ & - & $\begin{array}{l}39 \text { coffin nails, } 13 \text { nails, } 2 \text { screws, } 25 \text { upholstery tacks, } 1 \\
\text { jar of wood coffin fragments, } 3 \text { straight pin fragments, } 1 \\
\text { glass bead, } 1 \text { cloth fragment. Green stains on cranial vault }\end{array}$ \\
\hline 9 & $35 \pm 5$ & $\mathrm{M}^{e}$ & $\begin{array}{l}\text { White } \\
\text { Black }^{a 2}\end{array}$ & $5^{\prime} 11 " \pm 2.7 "$ & $\begin{array}{l}32 \text { coffin nails, } 1 \text { iron nail, } 2 \text { screws, } 2 \text { straight pin } \\
\text { fragments, } 3 \text { wooden buttons }\end{array}$ \\
\hline 10 & 0.1 & $?$ & $?$ & - & $\begin{array}{l}25 \text { coffin nails, } 4 \text { straight pin fragments. Greenish stains on } \\
\text { some vertebrae and ribs }\end{array}$ \\
\hline 11 & 0.08 & $?$ & $?$ & - & 24 coffin nails, 7 iron nails, 3 straight pins \\
\hline 12 & $7 \pm 2$ & $?$ & $(\text { Black })^{b 1}$ & - & 12 coffin nails, 24 nails, 2 spikes, 3 button fragments \\
\hline 13 & $>21$ & M?f & $?$ & - & $\begin{array}{l}4 \text { nails, } 22 \text { encrusted nails, } 2 \text { metal sheet fragments, } 16 \\
\text { wood fragments with tacks and fabric }\end{array}$ \\
\hline 14 & $20 \pm 3$ & $\mathrm{M}^{e}$ & Black $^{a 1 / 2}$ & $5^{\prime} 5^{\prime \prime} \pm 2.8^{\prime \prime}$ & 25 coffin nails, 1 button \\
\hline 15 & 0.08 & ? & $?$ & - & $\begin{array}{l}20 \text { coffin nails and fragments, } 1 \text { nail, } 1 \text { metal strap, } 8 \text { wood } \\
\text { coffin fragments, } 14 \text { straight pins }\end{array}$ \\
\hline 16 & $1 \pm 0.33$ & $?$ & $?$ & - & 23 coffin nails, 2 wood coffin fragments, 4 historic buttons \\
\hline 17 & $45 \pm 10$ & $\mathrm{M}^{d}$ & White? ${ }^{a l}$ & $?$ & $\begin{array}{l}70 \text { coffin nails, } 3 \text { coffin handles } \& 3 \text { fragments, } 1 \text { bag coffin } \\
\text { fragments, } 2 \text { historic buttons }\end{array}$ \\
\hline
\end{tabular}

$a$ : FORDISC 2.0 1) cranial, 2) postcranial; $b$ : based on 1) post-coronal depression of vault and 2) guttering of lower nasal border (Byers 2002:158-160); $c$ : FORDISC 2.0 multi-bone stature equations for adults. Sexing criteria based on: $d$ : cranial traits; $e$ : cranial and pelvic traits; f: long bone metrics (Buikstra \& Ubelaker 1994). 
Archival records on file at the Warren County Records Office in Warrenton, North Carolina, provide additional insights into the identity of the occupants. According to probate records, the land on which the cemetery was located during the years it was in use belonged to William Eaton, Sr. His father, Thomas Eaton, was tied with another landowner as the largest slaveholder in Warren County in $1790(\mathrm{n}=138$, Wellman 1959). When he died in 1809, Thomas Eaton bequeathed approximately 63 slaves to his son William, who remained a slaveholder in 1862 when his own will was drafted. On his death, William Eaton was buried in distinct cemetery on his land, presumably the family cemetery, that later became associated the Wesley Memorial Methodist Episcopal Church in Warrenton, North Carolina (Historical Records Survey of North Carolina 1942). Hence, the Eaton Ferry cemetery is an apparent African American cemetery located during its use on land owned by a slaveholding family, who buried their own dead in a geographically separate family cemetery. For these reasons, it seems likely that people buried in the cemetery were slaves of the Eaton family, and thus represent the sector of 19th century North Carolina society of interest to the research question.

Disease environment for African Americans in the antebellum South - Infectious disease was a prominent part of life and a significant cause of death for all people in the XIX Century South. For example, leading causes of death in North Carolina according to the 1850 census included: respiratory diseases $(10 \%)$, tuberculosis $(6.1 \%)$, typhoid fever (3.3\%), diarrheal diseases (3.2\%), diphtheria $(3.2 \%)$, scarlet fever (1.6\%), measles (1.1\%), and less specifically identified disease categories such as fevers (including malaria and yellow fever, $8.3 \%$ ), dropsy (7.1\%), nervous system diseases $(5 \%)$, digestive system diseases $(4.1 \%)$, and worms $(1.6 \%)$. These disease categories account for $54.6 \%$ of 10,165 deaths recorded in North Carolina that year (Patterson 1989:154). Leading causes of death among the slave population of Virginia for 1850 (including the latter part of 1849) are similar: respiratory diseases (16.1\%), tuberculosis $(10.7 \%)$, nervous system disease (including neurosyphilis) $(7.9 \%)$, typhoid $(5.7 \%)$, diarrhea $(5.5 \%)$, and cholera $(5.5 \%)$. It should be noted that these values differ little from those recorded for the white population of Virginia that year, although the order of disease prevalence differs slightly and diseases such as cholera that swept through the region four times between 1830 and 1850 were particularly devastating for slave and free black populations (Savitt 1978). On the other hand, diseases such as malaria and yellow fever that were particularly troublesome in the warm, humid conditions of the Southeast do not appear to have impacted people of African descent as severely as those of European descent, a fact widely noted by physicians of the time (Savitt 1978, 1989, Patterson 1989). Statistics are lacking on venereal disease, but rates of syphilis and gonorrhea - as indicated by physicians' casebooks, were characterized by one historian as "startling" (Genovese 1960, in Savitt 1978). Nutritional deficiency diseases such as rickets, scurvy, pellagra, and iron deficiency anemia are thought to have been common among blacks and poor whites, but are listed as only minor causes of death in the 1850 census records (Patterson 1989). The question therefore arises of whether the disease experience was really different for enslaved blacks and whites in the antebellum South. Emerging data suggest that it was, particularly for infants and children.

Opinion has varied widely concerning the health of slaves relative to that of the general population. Some have argued that slave health and mortality was similar to that of the free population (e.g. Fogel \& Engerman 1974), whereas others have presented a more grim picture (e.g. Postell 1951). Recent research based on mortality rates and stature estimates provides strong support for the latter perspective, particularly for the very young. Using these health measures, noted historian Richard H Steckel (2000:449 [quote]) concluded that "[slave] children's health was comparable to that in the poorest populations ever studied, whereas working-age slaves were remarkably well-off.....slave mortality rates were approximately 350 per thousand among infants and $200 \%$ at ages 1 to 4 . These childhood rates were roughly double those of the entire free population in the United States, but the rates of slave and free adults were approximately equal." Most babies fell below 5.5 pounds at birth and two-thirds of infants died within the first month, a pattern attributed to hard work required of pregnant mothers, especially during peak seasons (Steckel 2000). Neonatal tetanus (Trismus nascentium), transmitted through the umbilical stump as a result of improper handling, was also a common cause of death for these newborns, as was diarrhea, nervous system diseases (including neurosyphilis), whooping cough, and respiratory diseases (Savitt 1978).

Health stresses for infants continued unabated as mothers returned to work, necessitating supplemental feeding of infants with less nutritious and frequently contaminated paps and gruels, and early weaning by 9 months to a year. Average heights of slave children fell below the 0.5 percentile of modern height standards for the well nourished, reflecting continued health problems and growth impacts likely associated with a nutritionally poor diet emphasizing hominy and fat (Steckel 2000, Rathbun $\&$ Steckel 2002). Health improvements ensued only when children joined the work force and gained access to a worker's rations, although adult stature still remained at the low end of modern standards (Steckel 2000). These data suggest that the health impacts of slavery were greatest for infants and children, and that these impacts influenced people's health into adulthood. Therefore, it is hypothesized that: a) infants and children will show the greatest health stress in the Eaton Ferry Cemetery; and that b) health stress will be more apparent in the Eaton Ferry sample than in non-slave samples.

\section{MATERIALS AND METHODS}

The remains of the 17 individuals analyzed here are curated at the Research Laboratories of Archaeology at the University of North Carolina at Chapel Hill (Davis et al. 1996). Osteological data were initially recorded 
by the author in 1994 and updated on a recent visit in 2005. A detailed inventory was compiled for each skeleton. Age and sex determinations followed standard osteological protocols (Buikstra \& Ubelaker 1994). Metric and other observations were recorded by skeletal element.

In order to gain insight into population ('racial') affinity, which might be relevant to understanding health conditions for individuals in the sample, cranial and postcranial measurements of adults were analyzed whenever possible ( $\mathrm{n}=7$ individuals) using FORDISC 2.0 (Ousley \& Jantz 1996). The cranial analysis was limited to three 'racial' groups most likely to be represented in this XIX century North Carolina sample: American Indian, Black, and White (Pollitzer 1971); postcranial analysis offered only Black/White discrimination. Although determinations based on metric data are not necessarily definitive, particularly in cases of genetic admixture, they nonetheless provide an independent means of assessing the identity of those buried in the Eaton Ferry Cemetery.

Standard health indices were used to characterize health (Buikstra \& Ubelaker 1994). Indices of dental pathology included dental caries, antemortem tooth loss, and enamel hypoplasia. The presence and severity of enamel defects were recorded for each tooth, and teeth were conservatively scored as hypoplastic if defects could be detected by running the fingernail over the tooth surface. Observations of skeletal pathology included porotic hyperostosis/cribra orbitalia (anemia), periosteal lesions (infection, trauma, nutritional deficiency), and destructive lesions (infection, malignancy) (Ortner 2003). These were limited to visual assessment aided by a $10 \times$ hand lens and strong, oblique lighting.

\section{RESULTS}

The Eaton Ferry Cemetery sample includes the remains of six infants $(35 \%)$, one child $(6 \%)$, and one young and nine mature adults (59\%) (Table I, Fig. 1). Of the nine individuals for whom sex could be determined, five are male and four are female. Preservation varies from poor to excellent, resulting in fewer individuals for some indices than the total sample would indicate.

FORDISC 2.0 (Ousley \& Jantz 1996) craniometric assessment identified three females and one male as black; the other three males were classified as white, although in one case (Burial 17) results suggested genetic admixture (Tables I, II). Postcranial racial assessment agreed with one male classified as white (Burial 3) and one male classified as black (Burial 14). In a third case (Burial 9), cranial and postcranial 'race' assignments disagreed, again suggesting mixed European/African ancestry. Two additional individuals were classified as black based on cranial traits that have been shown to correlate with "racial" group: post-coronal depression and nasal guttering (Byers 2002). In sum, six individuals were classified as "black," two as "white"- with genetic admixture, and one as "white."

All scorable dentitions ( $>1$ years, $\mathrm{n}=10$ ) have carious teeth, and seven of nine observable jaws have remodeled sockets, indicating that at least one tooth was lost prior to death (Table III). The ten individuals that could be scored for dental/periodontal disease have an average of 12.3 diseased/missing teeth. No fillings, bridges, or other indicators of dental treatment are evident in the sample. The rate of carious teeth for females is $47.4 \%$, whereas males show a higher rate of $61.4 \%$, despite a younger mean age of males in the sample (male 35 years, female $=$ 41 years). When diseased teeth (carious, AMTL) are combined, this difference is less pronounced $(\mathrm{m}=65.5 \%, \mathrm{f}=$ $58.3 \%)$.

Eight of 10 individuals $(80 \%)$ for whom enamel hypoplasia of the canines and incisors could be scored are affected; the other two individuals have only two teeth
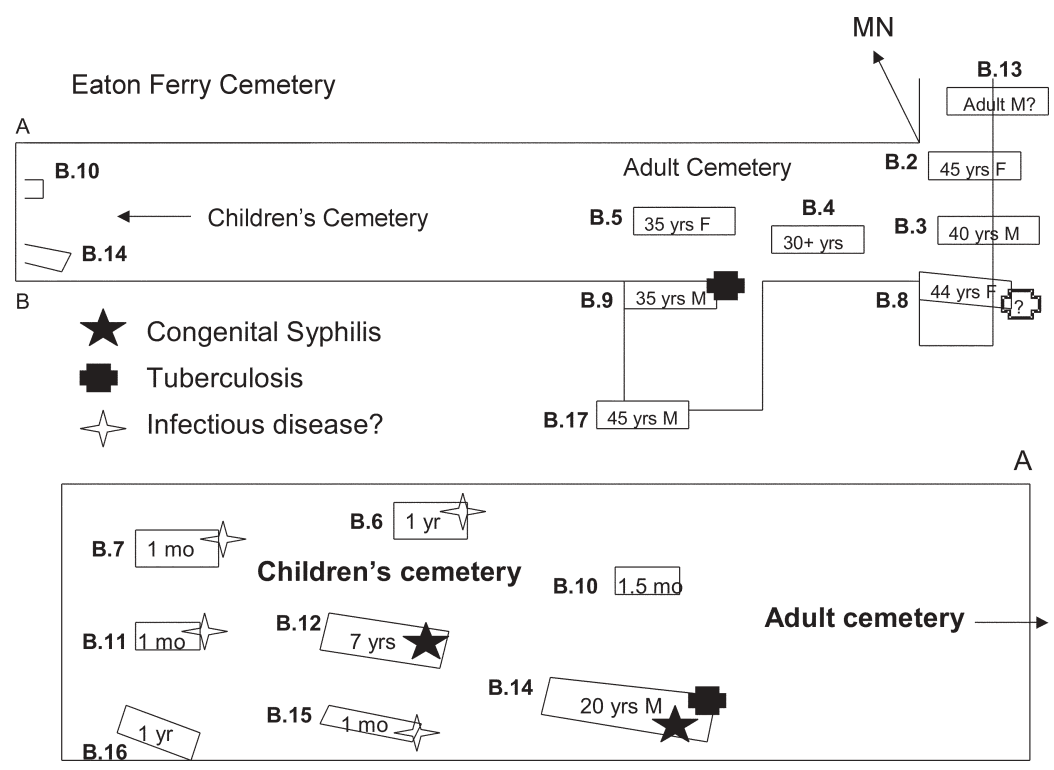

Fig. 1: map of the Eaton Ferry Cemetery, Warren County, North Carolina, including burial number, age, sex, and specific disease affliction. 
TABLE II

FORDISC 2.0 cranial and postcranial group classification probabilities (Ousley \& Jantz 1996) for seven adults in the Eaton Ferry Cemetery sample

\begin{tabular}{|c|c|c|c|}
\hline Burial (Sex) & $\begin{array}{l}\text { Group classification } \\
(n)=\text { number variables used in analysis }\end{array}$ & $\begin{array}{l}\text { Posterior } \\
\text { probability }\end{array}$ & Typicality \\
\hline 1 Female & $\begin{array}{l}\text { Cranial: Black (11) } \\
\text { White }\end{array}$ & $\begin{array}{l}.953 \\
.038\end{array}$ & $\begin{array}{l}.680 \\
.192\end{array}$ \\
\hline 2 Female & $\begin{array}{l}\text { Cranial: Black (4) } \\
\text { White }\end{array}$ & $\begin{array}{l}.671 \\
.290\end{array}$ & $\begin{array}{l}.521 \\
.297\end{array}$ \\
\hline 3 Male & $\begin{array}{l}\text { Cranial: White (18) } \\
\text { Black } \\
\text { Postcranial: White (9) } \\
\text { Black }\end{array}$ & $\begin{array}{l}.962 \\
.032 \\
.947 \\
.053\end{array}$ & $\begin{array}{l}.005 \\
.001 \\
.866 \\
.321\end{array}$ \\
\hline 8 Female & $\begin{array}{l}\text { Cranial: Black }(18) \\
\text { White }\end{array}$ & $\begin{array}{l}.723 \\
.267\end{array}$ & $\begin{array}{l}.092 \\
.057\end{array}$ \\
\hline 9 Male & $\begin{array}{l}\text { Cranial: White (15) } \\
\text { Black } \\
\text { Postcranial: Black (15) } \\
\text { White }\end{array}$ & $\begin{array}{l}.999 \\
.001 \\
.606 \\
.394\end{array}$ & $\begin{array}{l}.305 \\
.010 \\
.124 \\
.101\end{array}$ \\
\hline 14 Male & $\begin{array}{l}\text { Cranial: Black (5) } \\
\text { White } \\
\text { Postcranial: Black (16) } \\
\text { White }\end{array}$ & $\begin{array}{l}.905 \\
.072 \\
.565 \\
.435\end{array}$ & $\begin{array}{l}.009 \\
.001 \\
.073 \\
.064\end{array}$ \\
\hline 17 Male & $\begin{array}{l}\text { Cranial: White (5) } \\
\text { American Indian } \\
\text { Black }\end{array}$ & $\begin{array}{l}.524 \\
.252 \\
.225\end{array}$ & $\begin{array}{l}.549 \\
.361 \\
.337\end{array}$ \\
\hline
\end{tabular}

Primary FORDISC 2.0 cranial classification (White, Black, or Amerindian) followed by secondary cranial classification. FORDISC 2.0 postcranial classification provided where available.

each available for analysis, so it is not possible to know if their other anterior teeth were affected (Table III). Defects are slight-to-moderate in one infant and three 30-50 year old adults, moderate-to-severe in two other adults in this age range, and extremely severe in another two individuals, aged 7 (Burial 12) and 20 (Burial 14) (Fig. 2, 3a,b). In these individuals, the incisors and first permanent molars are also malformed.

Cranial pathology is less common than dental pathology, but affects at least four individuals (Table III). Three (27\%), including one infant and two mature adults, have porotic hyperostosis of the vault and/or eye orbits attributable to anemia. The infant with cribra orbitalia also has several additional pathological lesions of the frontal bone that include abnormal porosity, enlarged and abnormal vascular features, and a round, erosive lesion above the left eye orbit (Fig. 4). A fourth infant has superficial porosity over the surface of one scorable orbit that appears periosteal in origin and could be indicative of scurvy (Ortner 2003). A fifth individual (Burial 2) may have healed, gummatous lesions of the cranial vault, but poor preservation makes this assessment extremely problematic.

Three individuals have pathological lesions in the bones of the thorax, and excavation records indicate that a fourth individual did as well. One mature adult male (Burial 3) has Schmorl's nodes on T10-L4. Burial 9, a 35-year-old man, has a large resorptive lesion of the 4th lumbar vertebral body that shows signs of remodeling.
Burial 14 has partially remodeled periosteal lesions on the visceral surfaces of one lower right and five left middle ribs in the region of the angle (Fig. 3c). Burial 8, a 44-year-old woman, is described in excavation records as having "complete fusion of thoracic vertebrae into $90^{\circ}$ angle making the person a hunchback" (Phelps 1962), although these vertebral bones are not in the collection and the condition therefore could not be verified by the author.

Long bone pathology is present in four individuals (33\%) (Table III). Three 1-month-old infants have fiberbone periosteal lesions that appear to be pathological, although the periosteum is very active in infants of this age (Ditkowsky \& Goldman 1970) and normal bone growth cannot be ruled out in at least one case. The 20 -year-old male (Burial 14) with the disfiguring enamel defects and rib lesions has remodeled periosteal lesions of the tibiae (lateral midshafts) and medially bowed fibulae (Fig. 3d). A fifth individual, Burial 12, may have had a periosteal lesion on the distal shaft of the left humerus, but this observation is based on superficial evidence of slight swelling that may not be pathological.

There are also two cases of traumatic injury evident in the sample. A 35-year-old female has healed, pathological changes to her left acromion that probably resulted from traumatic injury. Burial 9, the male described above, has a fully healed shaft fracture of the left clavicle. 
TABLE III

Pathological conditions in the Eaton Ferry Cemetery sample (Affected/Total scorable)

\begin{tabular}{|c|c|c|c|c|c|c|c|}
\hline \multirow{2}{*}{$\begin{array}{l}\text { Burial No. } \\
\text { Age, Sex }\end{array}$} & \multicolumn{2}{|c|}{ Diseased teeth } & \multirow{2}{*}{$\begin{array}{l}\text { LEH incisors } \\
\text { and canines }\end{array}$} & \multicolumn{2}{|c|}{ Porotic hyperostosis } & \multirow{2}{*}{$\begin{array}{l}\text { Long bone } \\
\text { pathology }\end{array}$} & \multirow{2}{*}{$\begin{array}{l}\text { Other pathological } \\
\text { lesions/conditions }\end{array}$} \\
\hline & Carious & AMTL & & Vault & Orbits & & \\
\hline $139 \mathrm{yrs}, \mathrm{F}$ & $1 / 3$ & 6 & $?$ & 0 & $0 / 1$ & $?$ & \\
\hline $245 \mathrm{yrs}, \mathrm{F}$ & $2 / 5$ & 7 & $2 \mathrm{~S}, 1 \mathrm{M}-\mathrm{V} / 3$ & $?$ & $1 / 1 \mathrm{M}$ & $?$ & Gummatous parietals??? ${ }^{a}$ \\
\hline $340 \mathrm{yrs}, \mathrm{M}$ & $7 / 21$ & 7 & $6 \mathrm{M}-\mathrm{V} / 11$ & 0 & $0 / 2$ & $0 / 9$ & Schmorl's nodes on T10-L4 \\
\hline $4>30 \mathrm{yrs}$ & $?$ & $?$ & $?$ & 0 & $?$ & $?$ & \\
\hline $535 \mathrm{yrs}, \mathrm{F}$ & $12 / 22$ & 0 & $0 / 2$ & $?$ & $0 / 2$ & $0 / 6$ & Injury/infection of left acromion \\
\hline $61 \mathrm{yr}$ & - & - & $2 / 11 \mathrm{~d}$ & $1 \mathrm{SA}$ & $2 / 2 \mathrm{SA}$ & $?$ & $\begin{array}{l}\text { Fine channeling at glabella, } \\
\text { enlarged vascular channel lateral } \\
\text { to L orbit, round lesion above L } \\
\text { orbit. Open channels lateral to } \\
\text { frontal crest on endocranial } \\
\text { surface, associated porosity }\end{array}$ \\
\hline $71 \mathrm{mo}$ & - & - & $?$ & 0 & $0 / 2$ & $\begin{array}{l}\quad 4 / 12 \\
\text { Fiberbone } \\
\text { lesions on ulnae } \\
\text { and tibiae }\end{array}$ & $\begin{array}{l}\text { Fiberbone on some ribs, could } \\
\text { be normal growth. }\end{array}$ \\
\hline $844, \mathrm{~F}$ & $12 / 27$ & 2 & $2 \mathrm{~S} / 12$ & 0 & $0 / 2$ & $0 / 7$ & $\begin{array}{l}\text { Complete fusion of thoracic } \\
\text { vertebrae into } 90^{\circ} \text { angle. } \\
\text { Pott's disease? }\end{array}$ \\
\hline $935, \mathrm{M}$ & $18 / 23$ & 3 & 4S-M/12 & $1 \mathrm{MH}$ & $2 / 2 \mathrm{MH}$ & $0 / 12$ & $\begin{array}{l}\text { Healed fracture of left clavicle; } \\
\text { large resorptive lesion of } 4 \text { th } \\
\text { lumbar vertebral body. }\end{array}$ \\
\hline $101.5 \mathrm{mo}$ & - & - & $?$ & 0 & $0 / 2$ & $0 / 12$ & \\
\hline $111 \mathrm{mo}$ & - & - & $?$ & $?$ & $0 / 2$ & $\begin{array}{l}\quad 2 / 12 \\
\text { Fiberbone } \\
\text { lesions on } \\
\text { humeri }\end{array}$ & $\begin{array}{l}\text { Costal rib ends have woven- } \\
\text { porous appearance-could be } \\
\text { normal. }\end{array}$ \\
\hline $127 \mathrm{yrs}$ & $\begin{array}{c}8 / 12 \mathrm{dec} \\
0 / 6\end{array}$ & $1 \mathrm{dm}_{2}$ & $\begin{array}{l}6 \mathrm{M}-\mathrm{V} / 6 \mathrm{~d} \\
6 \mathrm{~V} / 6\end{array}$ & 0 & $0 / 2$ & $0 / 12$ & $\begin{array}{l}\text { Possible swelling on distal shaft } \\
\text { of left humerus-fully remodeled. }\end{array}$ \\
\hline $13>21$ yrs, M? & $6 / 7$ & $?$ & $0 / 2$ & $?$ & $?$ & $0 / 1$ & \\
\hline $1420 \mathrm{yrs}, \mathrm{M}$ & $26 / 32$ & 0 & $12 \mathrm{~V} / 12$ & 0 & $0 / 2$ & $\begin{array}{l}\quad 4 / 12 \\
\text { Remodeling } \\
\text { periosteal } \\
\text { lesions on tibiae. } \\
\text { Medially bowed } \\
\text { fibulae }\end{array}$ & $\begin{array}{l}\text { Periosteal lesions on visceral } \\
\text { surfaces of } 5 \text { left ribs and } 1 \text { right } \\
\text { rib on angle, some remodeling. }\end{array}$ \\
\hline $151 \mathrm{mo}$ & - & - & $?$ & 0 & $?$ & $\begin{array}{l}\quad 6 / 10 ? \\
\text { Fiberbone on } \\
\text { humeri, femora } \\
\text { \& tibiae-- } \\
\text { pathological? }\end{array}$ & $\begin{array}{l}\text { Fine, superficial porosity over } \\
\text { surface of left orbit. Right orbit } \\
\text { unscorable }\end{array}$ \\
\hline $161 \mathrm{yr}$ & - & - & $?$ & $?$ & $?$ & $?$ & \\
\hline $1745 \mathrm{yrs}, \mathrm{M}$ & $5 / 18$ & 2 & $2 \mathrm{M} / 6$ & 0 & $?$ & $0 / 2$ & \\
\hline Total affected & $10 / 10$ & $7 / 9$ & $8 / 10$ & $2 / 12$ & $3 / 12$ & $4 / 12$ & \\
\hline Individuals & $(100 \%)$ & $(78 \%)$ & $(80 \%)$ & $(17 \%)$ & $(25 \%)$ & $(33 \%)$ & \\
\hline
\end{tabular}

Severity, S: slight, M: moderate, V: severe; Healing status, A: active, H: healed; a: poor preservation; AMTL: number of teeth lost antemorten; LEH: number of teeth with linear enamel hypoplasia. 

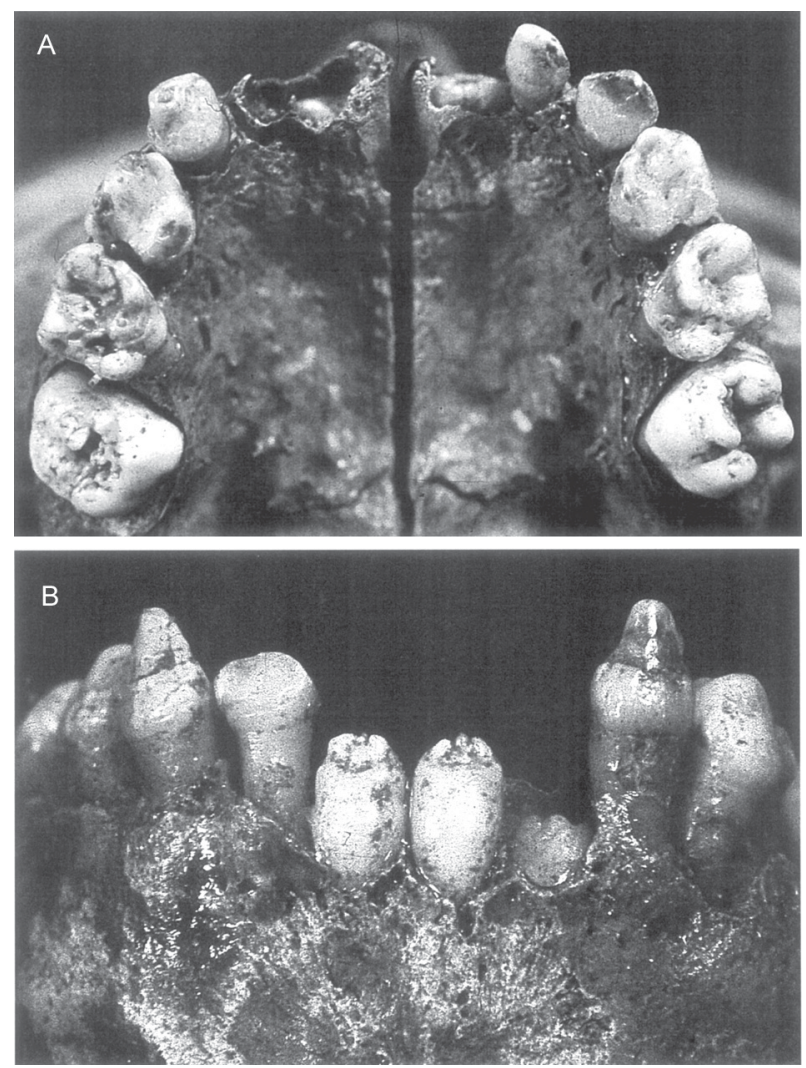

Fig. 2: dental lesions suggestive of congenital syphilis in 7-year-old child, Burial 12. A: enamel hypoplasia and mulberry molars of the maxillary dentition; B: enamel hypoplasia and Hutchinson's incisors of the mandibular dentition.

\section{DISCUSSION}

The social and economic status of individuals buried in the Eaton Ferry Cemetery provides a starting point for understanding health conditions and risks in the community from which they derive. The analysis of group affiliation (Tables I, II) strongly supports the argument that most if not all of the individuals buried in the cemetery are of African descent. Because "Black/African American" is as much a social as biological construct in the United States, even those classified as "white" by FORDISC 2.0 could have had some degree of African ancestry and been considered black (for example, see Rose 1985), thus subject to social and economic restrictions and limitations of the 19th century South. This seems likely given the rarity of racial mixing in cemeteries of this place and time.

The high rate of dental disease observed in the Eaton Ferry Cemetery sample is not surprising, given the emphasis on corn in the southern diet (Patterson 1989), and particularly among slaves (Savitt 1978). Numerous studies of prehistoric Native Americans have documented the cariogenic nature of corn, and one of the major impacts of the transition to maize agriculture in the Americas is a profound increase in rates of dental caries (e.g., see Larsen 1997, Lambert 2000). It is interesting that the dentitions of the men are somewhat more diseased than those of the women, because the opposite in generally
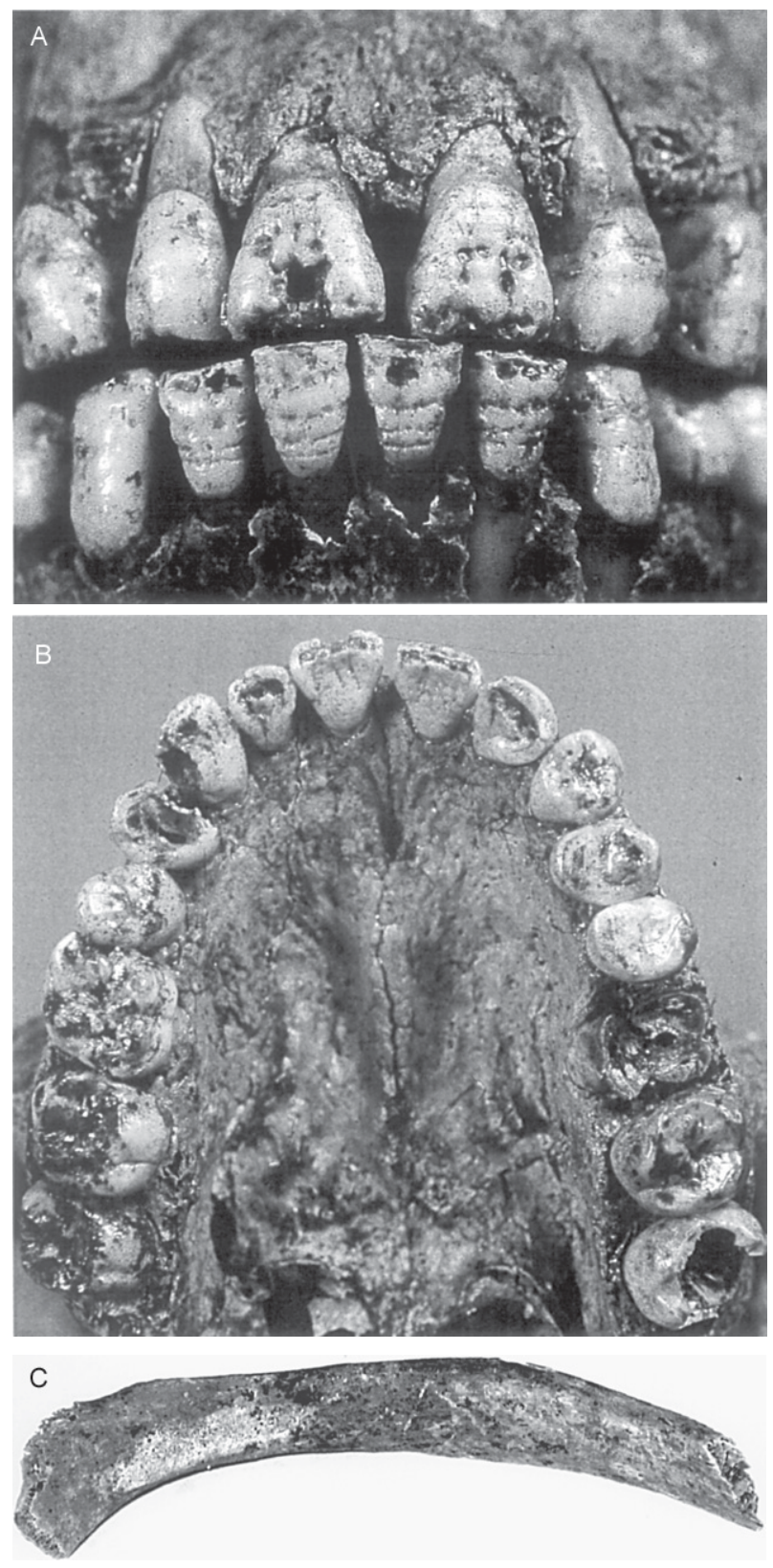

D

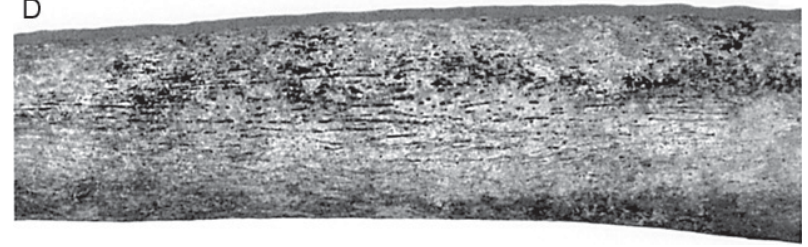

Fig. 3: dental and skeletal lesions suggestive of congenital syphilis and tuberculosis in young adult, Burial 14. A: enamel hypoplasia of the maxillary dentition, B: occlusal view of dental defects, including mulberry molar of the right M1; C: periosteal lesion of a left rib; D: periosteal lesion of the left tibia, lateral shaft.

true in prehistoric agriculturalists (e.g., Lambert 2000). Perhaps this reflects gender differences in diet, hygiene, or other practices that predispose teeth to cavities, though it may simply be a product of small sample size. Pat- 
terns are mixed in other historic, black samples (Rathbun \& Steckel 2002), so Eaton Ferry neither conforms with nor stands out from these other samples. The mean value for diseased teeth of females $(\overline{\mathrm{X}}=11)$ falls between mean values reported for females in two black South Carolina plantations samples, but is higher for Eaton Ferry males $(\overline{\mathrm{X}}=15)$ than for males in this samples (Remley Plantation, ca. 1738-1756: male $\overline{\mathrm{x}}=9$, female $\overline{\mathrm{x}}=16$; Belleview Plantation, ca. 1840-1870: male $\bar{x}=11$, female $\bar{x}=9$ ). All differ substantially from rates (male $\bar{x}=$ 0 , female $\bar{x}=3$ ) reported for a sample of Charleston elites (ca. 1750-1850), one of whom even had gold fillings (Rathbun \& Steckel 2002), illustrating the influence of wealth on dental health as well as the role of poverty in its decline.

The high rate of enamel hypoplasia ( $80 \%$ of individuals affected) provides strong support for the argument that the health of slave children was particularly compromised during the six year period (0-6 years) when these lesions form in growing incisor and canine tooth crowns (Buikstra \& Ubelaker 1994). When this rate is broken down by sex and tooth type, the sexes appear similarly affected (male incisors $40 \%$, canines $80 \%$; female incisors $50 \%$; canines $100 \%$ ). These rates by tooth type are somewhat higher than those reported for the two plantation samples noted above $($ males $=23 \% \& 80 \%$, females $=7 \% \& 50 \%$,
Remley Plantation; males $=25 \% \& 50 \%$, females $=40 \% \&$ $40 \%$, Belleview Plantation) and much higher than those recorded for the Charleston elites $($ male $=$ n.a. $\% \& 36 \%$, female $=0 \% \& 20 \%$ ). The only other sample that approaches these levels in the data series compiled by Rathbun and Steckel (2002) is the free black cemetery at Cedar Grove (1881-1927) in rural Arkansas (male $=67 \%$ \& $80 \%$, female $=48 \% \& 62 \%$ affected incisors $/$ canines , which may be a reflection of rural poverty more generally, but might also reflect the social and economic impacts of late XIX century Jim Crow laws.

A number of osteological studies of XIX century slave and free black cemetery samples (e.g. Rose 1985, Hutchinson 1987, Owsley et al. 1987, Rathbun 1987, Jacobi et al. 1992, Blakey et al. 1994, Rankin-Hill 1997, Rathbun \& Steckel 2002) have explored the prevalence of infectious diseases and other disorders. Diseases noted in these studies and of particular interest here, given their potential to produce dental defects and other lesions observed in the Eaton Ferry skeletal series, include congenital syphilis (Rose 1985, Rathbun 1987, Jacobi et al. 1992), tuberculosis (Rose 1985, Angel et al. 1987, Kelley \& Angel 1987, Rankin-Hill 1997), marasmus (Blakey et al. 1994), rickets, scurvy (Rose 1985, Rankin-Hill 1997), and sickle-cell anemia (Angel et al. 1987, Rathbun 1987). The cranial, dental, and postcranial signs of these diseases/disorders

TABLE IV

Diagnostic criteria for diseases/disorders suspected in the Eaton Ferry Cemetery sample

\begin{tabular}{llll}
\hline Disorder & Dental Defects & Cranial & Postcranial \\
\hline $\begin{array}{l}\text { Congenital Syphilis }{ }^{a-c} \\
\text { (may lead to rickets) }\end{array}$ & $\begin{array}{l}\text { Barrel-shaped, notched } \\
\text { incisors and mulberry molars. }\end{array}$ & $\begin{array}{l}\text { Necrotizing osteitis (round, } \\
\text { destructive lesions). Osteo- }\end{array}$ & $\begin{array}{l}\text { Osteochondritis/osteoperiostitis at } \\
\text { 0-5 years. Gummatous osteomyelitis, } \\
\end{array}$ \\
$\begin{array}{l}\text { Linear enamel hypoplasia } \\
\text { may be present. }\end{array}$ & $\begin{array}{l}\text { periostitis of the skull (rare). } \\
\text { esp. of tibiae, \&. bone deformities }\end{array}$ \\
& Reduced tooth size & involvement naso-palatal & $\begin{array}{l}\text { such as saber-shin tibia relatively } \\
\text { common at 5-15 years. }\end{array}$ \\
& & & Dactylitis may be present
\end{tabular}

Malnutrition ${ }^{a-e}$ (increased susceptibility to infectious diseases)

Linear enamel hypoplasia, reduced tooth size, fluctuating dental asymmetry

Rickets ${ }^{a, b}$

Sickle Cell Anemia ${ }^{f-h}$ (increases susceptibility to infection)

Tuberculosis $a, b, i, j$ (opportunistic infection)
Linear enamel hypoplasia, especially in maxillary incisors Marked changes may also be seen in deciduous and permanent molar tooth crowns

Hypomineralization of dentin and enamel. Hypercementosis of tooth roots. Malocclusion. Possible tooth discoloration

Linear enamel hypoplasia, including multiple bands, may be present in tooth crowns
Porotic hyperostosis from iron deficiency. Porous appositional lesions of sphenoid, eye orbits, and vault in cases of scurvy

Craniotabes (localized thinning Hypertrophy \& possible cupping of of vault bones), especially in long bone metaphyses in infancy. infancy. Thickening (bossing) Demineralization leading to of frontal and parietal bones due to bone deposition most common in 2-3 year range

Porotic hyperostosis. Periodontal disease: marked loss of alveolar bone. Predisposition of jaw bones to infection and osteomyelitis

Destructive lesions of skull and face possible, but uncommon overall
Growth retardation, reduced adult stature, Harris lines, periosteal lesions from subperiosteal hemorrhage in cases of scurvy fracturing and bowing, esp. of leg bones. Beading of sternal rib ends. Rickets most common from 6 months2 years and 6-15 years

Medullary hypertrophy and thinning of cortices of long bones. Growth retardation of one or more bones. Increased susceptibility to infections that can affect postcranial bones

Periosteal lesions of visceral rib surfaces possible. Destructive lesions of spine, hips, knees, and other bones

a: Ortner 2003; $b$ : Steinbock 1976; $c$ : Rasool \& Govender 1989; $d$ : Larsen 1997; $e$ : Zhou \& Corruccini 1998; $f$ : Richard 1977; $g$ : Sanger \& McTigue 1978; $h$ : Oredugba \& Savage 2002; $i$ : Roberts et al. 1994; $j$ : Lambert 2002. 

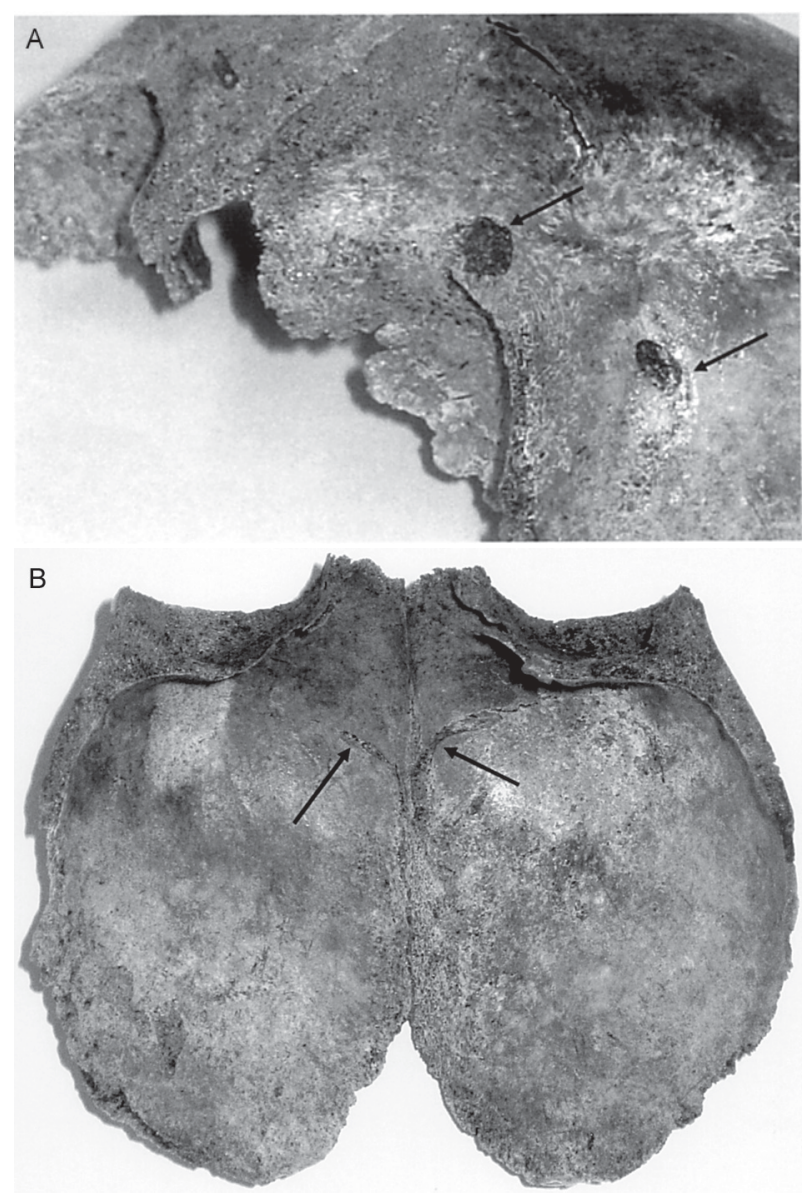

Fig. 4: pathological cranial lesions in 1-year-old infant, Burial 6. A: ectocranial lesions of frontal bone; B: endocranial channeling of frontal bone.

are described in Table IV.

Four individuals in the Eaton Ferry sample have dental/skeletal indicators strongly suggestive of a particular infectious disease (Burials 8, 9, 12, and 14) and two others are suggestive. The dental evidence observed in Burials 12 and 14 appears to most closely match the diagnostic criteria for congenital syphilis (Hillson et al. 1998, Table IV, Figs 2, 3). Both have misshapen, mulberry first molars as well as barrel-shaped and/or notched incisors of the permanent dentition. Although neither individual exhibits signs of cranial involvement or evidence of osteochondritis, Burial 14 has remodeled periosteal lesions on the midshafts of both tibiae, a common location for these lesions in treponemal disease (Steinbock 1976, Ortner 2003). If the poorly preserved cranial vault of Burial 2 was in fact affected with gummatous lesions (Table III), this would be a third individual affected with venereal syphilis and not surprising in light of the evidence for the congenital form of the disease. Three individuals appear to have suffered from tuberculosis, which greatly troubled African American communities of the 19th century (Rose 1985, Rankin-Hill 1997, Figs 1, 3c). One is Burial 14, the young man with evidence of congenital syphilis. This individual has signs of pulmonary infection in the form of rib lesions on visceral ribs surfaces. In studies of identified skeletons, this type of rib lesion has been found to positively correlate with pulmonary infections, particularly the pulmonary form of tuberculosis (see Roberts et al. 1994, Lambert 2002). Burial 9, a mature adult male, has a large resorptive lesion of the 4th lumbar vertebra that is strongly suggestive of skeletal tuberculosis (Ortner 2003). Burial 8 also appears to have been afflicted with skeletal tuberculosis in the form of Pott's disease (Table III; see Roberts \& Buikstra 2003), although it is possible this woman suffered instead from senile or secondary kyphosis (Ortner 2003).

One or more of the three neonates (Burials 7,11 and 15 ) with fiberbone lesions on various long bones could have been affected with early stage congenital syphilis, known to cause osteoperiostitis (Table IV). However, these infants could also have been infected with strep, staph, or other bacterial infections known to cause appositional lesions (Steinbock 1976, Ortner 2003). Given the range of diseases listed as primary causes of death for slave infants (Savitt 1978), the possibilities are many.

Malnutrition was likely a contributing factor in the poor health and early death of subadults in the Eaton Ferry Cemetery. The 7-year-old child with apparent congenital syphilis is very small (4.5 years) for a dental age of 7 years (Ubelaker 1984, Table V), which is consistent with chronic malnourishment, although chronic disease can also impact growth and development (Goodman 1991). Early weaning could have put infants at risk for scurvy and rickets, as may be indicated by porous cranial lesions in the two, year-old infants in the sample (Burials 6 and 16, see Ortner et al. 2001, Ortner 2003). On the other hand, the inward bowing of Burial 14's fibulae, a malformation that can be caused by rickets (Ortner 2003), seems unlikely to be so in this case, given the absence of bowing in the tibiae; this bowing may instead be the result of postmortem, taphonomic processes.

It is also possible that sickle-cell anemia was a complicating factor in one or more of these individuals. Although this genetic disorder was not recognized or understood in the mid-XIX century, physicians of the time nonetheless noted the resistance of many African Americans to malaria-a resistance conferred almost certainly in part by possession of the sickle-cell trait (Savitt 1989). Sickle-cell anemia can leave its mark on the skeleton in a number of ways (Richard 1977, Sanger \& McTigue 1978, Oredugba \& Savage 2002, Table IV), including porotic hyperostosis. However, there were only a few cases of porotic hyperostosis in the sample (25\%) and none was particularly severe. Burial 12 , who lost the left $\mathrm{m} 2$ prematurely in cause or consequence of alveolar bone loss - a common affliction in children with sickle-cell anemia (Sanger \& McTigue 1978) - may have suffered from the disorder, though this child showed no specific signs of anemia and tooth loss may have related to infection with syphilis. The one-yearold infant (Burial 6) with cranial lesions is another possibility, given the presence of porotic hyperostosis and vascular abnormalities, but young infants ( $<2$ years) are 
rarely affected with active hemolytic disease due to the late exchange of fetal for adult hemoglobin (Sanger \& McTigue 1978), making this diagnosis unlikely.

\section{Concluding remarks}

In summary, there is evidence for two specific infectious diseases in the Eaton Ferry Cemetery that are known from historic records to have troubled XIX century African Americans: tuberculosis and syphilis. These and other diseases no doubt contributed to the deaths of seven infants and children, and perhaps also to the childhood growth disruption observed in the teeth of six adults. These high rates of childhood affliction support the hypothesis that infants and children were a particularly vulnerable segment of the enslaved African American population in North Carolina. While the sample is small, the cumulative picture of health stress in the Eaton Ferry sample nonetheless provides compelling evidence for the steep biological costs of slavery, particularly for the youngest of the enslaved.

\section{ACKNOWLEDGMENTS}

To the editors for their invitation to participate in this special issue. To Clark Spencer Larsen for his guidance during my analysis of the North Carolina Collections. At UNC-Chapel Hill, RP Steven Davis kindly provided copies of excavation records and facilitated access to the collections and Brett Riggs offered important insights on the dating of artifacts from the site. Elizabeth Cheatham conducted the initial archival research on the cemetery and Eaton family, and Patricia Samford facilitated a later stage of this work and I thank them for their efforts. The analysis was funded in part by the Research Laboratories of Archaeology at the University of North Carolina at Chapel Hill.

\section{REFERENCES}

Angel JL, Kelley JO, Parrington M, Pinter S 1987. Life stresses of the free Black community as represented by the First African Baptist Church, Philadelphia, 1823-1841. Am J Phys Anthropol 74: 213-231.

Blakey ML, Leslie TE, Reidy JP 1994. Frequency and chronological distribution of dental enamel hypoplasia in enslaved African Americans: a test of the weaning hypothesis. Am J Phys Anthropol 95: 371-384.

Buikstra JE, Ubelaker D 1994. Standards for Data Collection from Human Skeletal Remains, Arkansas Archaeological Survey Research Series, 44, Fayetteville, 206 pp.

Byers SN 2002. Introduction to Forensic Anthropology, Allyn \& Bacon, Boston, 444 pp.

Davis RPS, Lambert PM, Steponaitis VP, Larsen CS, Ward HT 1996. NAGPRA Inventory of the North Carolina Collection, Research Laboratories of Archaeology, University of North Carolina, Chapel Hill.

Ditkowsky SP, Goldman A 1970. Normal periosteal reactions and associated soft-tissue findings: relationship to infantile colic and to the Caffey Syndrome. Clinical Pediatrics 9: 515-524.

Fogel RW, Engerman SL 1974. Time on the Cross: The Economics of American Negro Slavery, Little Brown, Boston, $304 \mathrm{pp}$.

Genovese E 1960. The medical and insurance costs of slave- holding in the cotton belt. J Negro History 45: 151.

Goodman AH 1991. Health, adaptation, and maladaptation in past societies. In H Bush, M Zvelebil (eds), Health in Past Societies: Biocultural Interpretations of Human Skeletal Remains in Archaeological Contexts, BAR International Series 567, Oxford (UK), p. 31-38.

Hillson S, Grigson C, Bond S 1998. Dental defects of congenital syphilis. Am J Phys Anthropol 107: 25-40.

Historical Records Survey of North Carolina 1942. Cemetery records of Warren County, NC, bound notes on file, Halifax County Library, Halifax.

Hutchinson J 1987. The age-sex structure of the slave population in Harris County, Texas: 1850 and 1860. Am J Phys Anthropol 74: 231-238.

Jacobi KP, Cook DC, Corruccini RS, Handler JS 1992. Congenital syphilis in the past: slaves at Newton Plantation, Barbados, West Indies. Am J Phys Anthropol 89:145-158.

Kane JN 1997. Necessity's Child: The Story of Walter Hunt, America's Forgotten Inventor, McFarland \& Co., Jefferson, $\mathrm{NC}, 318 \mathrm{pp}$.

Kelley JO, Angel JL 1987. Life stresses of slavery. Am J Phys Anthropol 74: 199-212.

Lambert PM 2000. Life on the periphery: health in farming communities of interior North Carolina and Virginia. In PM Lambert, Bioarchaeological Studies of Life in the Age of Agriculture: A View from the Southeast, University of Alabama Press, Tuscaloosa, p. 158-194.

Lambert PM 2002. Rib lesions in a prehistoric Puebloan sample from Southwestern Colorado. Am J Phys Anthropol 117: 281-292.

Larsen CS 1997. Bioarchaeology: Interpreting Behavior from the Human Skeleton, Cambridge University Press, Cambridge, $461 \mathrm{pp}$.

McNulty M 2006. How products are made: straight pins. http:/ /science.enotes.com/how-products-encyclopedia/straightpin.

Oredugba FA, Savage KO 2002. Anthropometric finding in Nigerian children with sickle cell disease. Pediatric Dentistry 24: 321-325.

Ortner DJ 2003. Identification of Pathological Conditions in Human Skeletal Remains, 2nd ed., Smithsonian Institution Press, Washington, D.C., 645 pp.

Ortner DJ, Butler W, Cafarella J, Milligan L 2001. Evidence of probable scurvy in subadults from archaeological sites in North America. Am J Phys Anthropol 114: 343-351.

Ousley SD, Jantz RL 1996. FORDISC 2.0: Personal Computer Forensic Discriminant Functions, Forensic Anthropology Center, University of Tennessee, Knoxville.

Owsley DW, Orser, CE, Mann, RW, Moore-Jansen PH, Montgomery RL 1987. Demography and pathology of an urban slave population from New Orleans. Am J Phys Anthropol 74: 185-198.

Patterson KD 1989. Disease environments of the antebellum south. In RL Numbers, TL Savitt (eds), Science and Medicine in the Old South, Louisiana State University Press, Baton Rouge, p. 152-165. 
Phelps DS 1961. Wr-4b site record. On file. Research Laboratories of Archaeology, University of North Carolina, Chapel Hill.

Phelps DS 1962. Burial 8 data form. On file, Research Laboratories of Archaeology, University of North Carolina, Chapel Hill.

Pollitzer WS 1971. Physical Anthropology of Indians of the Old South. In CM Hudson, Red, White, and Black: Symposium on Indians in the Old South, Southern Anthropological Society Proceedings, No. 5, Athens, GA, p. 31-43.

Postell, WD 1951. The Health of Slaves on Southern Plantations, Louisiana State University Press, Baton Rouge, 231 pp.

Rankin-Hill LM 1997. A Biohistory of $19^{\text {th }}$ Century Afro-Americans: The Burial Remains of a Philadelphia Cemetery, Bergin and Garvey, Westport, 203 pp.

Rasool MN, Governder S 1989. The skeletal manifestations of congenital syphilis: a review of 197 cases. J Bone Joint Surg 71-B: 752-755.

Rathbun TA 1987. Health and disease at a South Carolina plantation: 1840-1870. Am J Phys Anthropol 74: 239-254.

Rathbun TA, Steckel RH 2002. The health of slaves and free Blacks in the East. In RH Steckel RH, JC Rose (eds), The Backbone of History: Health and Nutrition in the Western Hemisphere, Cambridge University Press, Cambridge, p. 208-225.

Richard PA 1977. Pathophysiology of dental changes in sickle cell disease. J Connecticut St Dent Ass 51: 20-23.

Roberts CA, Buikstra JE 2003. The Bioarchaeology of Tuberculosis: A Global View on a Reemerging Disease, University Press of Florida, Gainesville, 343 pp.

Roberts C, Lucy D, Manchester K 1994. Inflammatory lesions of ribs: an analysis of the Terry Collection. Am J Phys
Anthropol 95: 169-0182.

Rose JC 1985. Gone to a Better Land: A Biohistory of a Rural Black Cemetery in the Post-Reconstruction South, Arkansas Archaeological Survey Research Series No. 25, Fayetteville, AR, $216 \mathrm{pp}$.

Sanger RG, McTigue, DJ 1978. Sickle cell anemia - Its pathology and management. J Dent Handicap 3: 9-21.

Savitt TL 1978. Medicine and Slavery: The Diseases and Health Care of Blacks in Antebellum Virginia, University of Illinois Press, Urbana, 332 pp.

Savitt TL 1989. Black health on the plantation: masters, slaves, and physician. In RL Numbers, TL Savitt (eds), Science and Medicine in the Old South, Louisiana State University Press, Baton Rouge, p. 327-356.

Sprague R 2002. China or Prosser button identification and dating. Historical Archaeol 36: 2: 111-127

Steckel RH 1985. The Economics of U.S. Slave and Southern White Fertility, Garland Publishing Inc., New York, 253 pp.

Steckel RH 2000. The African American population of the United States, 1790-1920. In MR Hains, RH Steckel (eds), A Population History of North America, Cambridge University Press, Cambridge, p. 433-481.

Steinbock RT 1976. Paleopathological Diagnosis and Interpretation, Charles C Thomas, Springfield, $423 \mathrm{pp}$.

Ubelaker DH 1984. Human Skeletal Remains, Taraxacum, Washington D.C., 119 pp.

Wellman MW 1959. The County of Warren North Carolina 1586-1917, University of North Carolina Press, Chapel Hill, $282 \mathrm{pp}$.

Zhou L, Corruccini RS 1998. Enamel hypoplasias related to famine stress in living Chinese. Am J Human Biol 10: 723-733. 
